\title{
In the Shadow of Florence
}

\section{Provincial Society in Renaissance Pescia}

JUDITH C. BROWN, University of Maryland. This study of the effects of imperialism on a conquered territory also offers an analysis of economic development in an age of nascent capitalism. "A distinguished, admirably balanced, original achievement; a truly important book."-Domenico Sella, University of Wisconsin-Madison. "A solid, meticulously crafted monograph on an important topic that has been little studied. Traditional views of provincial Tuscany will have to be reconsidered in the light of this revisionist study." - Gene A. Brucker, University of California, Berkeley. "Illuminates Renaissance economy and state. A book rewarding to read, and sure to be imitated." - David Herlihy, Harvard University.

April 1982

$272 \mathrm{pp}$.

$\$ 29.50$

\section{The Economic History of Eastern Europe 1919-75}

Volume I: Economic Structure and Performance between the Two Wars

M.C. KASER and E.A. RADICE, both of the University of Oxford. This is the first volume of five which will together encompass a period defined by the two treaties fundamental to the formation of contemporary Europe-Versailles in 1919 and Helsinki in 1975. This comparative economic study treats the transformation of a quarter of the European continent from a predominantly agrarian to an overwhelmingly industrial society.

June 1982

$576 \mathrm{pp}$.

$\$ 62.50$

\section{Anglo-American Economic Collaboration in War and Peace 1942-1949}

SIR RICHARD CLARKE; edited by SIR ALEC CAIRNCROSS, University of Glasgow. This highly readable and perceptive account of the dilemmas of policy facing the British government in its collaboration with the United States, from Lend Lease to the Marshall Plan, gives a vivid picture of a country exhausted by war and crippled by debt but expected to play a leading role, in partnership with America, in the post-war reconstruction of the world economy.

March 1982 $208 \mathrm{pp}$.

Prices and publication dates are subject to change.

OXFORD UNIVERSITY PRESS 200 Madison Avenue $\cdot$ New York, N.Y. 10016

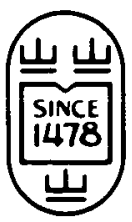




\section{Insights into historical economic change... from Academic Press}

\section{Explorations in the New Economic History}

Essays in Honor of Douglass North Edited by ROGER L. RANSOM, RICHARD SUTCH, and GARY M. WALTON

This book is a collection of essays by thirteen eminent economic historians on topics of interest to economists, economic historians, and quantitative historians. In the first of the three sections of this book, Richard Sutch assesses North's contributions and scholarship with respect to the New Economic History. The second section contains essays that deal with what North considers to be two grand topics in economic history: growth and welfare. Here, chapters deal with such topics as models of export-led economic growth; the phenomena of "regenerative" growth following wartime devastation, and measuring the "burden" of the Navigation Acts on the thirteen American colonies. In this section you will also find papers that concern themselves with the problems of welfare in industrial societies and with ways in which economic security can be enhanced. Part III, Property Rights and Institutional Change, contains papers that discuss such topics as the impact of changing property rights in Britain during the early years of industrialization, the use of the judiciary as an agency to support efforts to effect transfers from one group to another, and an examination of customary law and property rights in China - to show that important insights can be gained by extending economic analysis to such societies.

1981, 312 pp., $\$ 34.50$ ISBN: 0-12-580080-0

\section{Market Institutions and Economic Progress in the New South 1865-1900}

\section{Essays Stimulated by One Kind of}

Freedom: The Economic Consequences of Emancipation

Edited by GARY M. WALTON and JAMES F. SHEPHERD

This book examines the economic institutions that replaced slavery in the postbellum South and analyzes the conditions under which ex-slaves were allowed to enter the economic life of the United States after the Civil War. The examinations are based upon quantitative data to determine the forces of retardation and the failure of the economy to diversify and modernize. The book critically examines and reassesses recent findings and conclusions published in One Kind of Freedom by Roger Ransom and Richard Sutch. The authors, all experts on the South and highly regarded professional economists, have written chapters that provide a lively and extensive debate. The book's new insights improve our understanding of the sources of racism and restriction in the new south in the late nineteenth century. The chapters of the book are edited versions of papers appearing in a special issue of the journal Explorations in Economic History.

1981, 176 pp., \$17.50 ISBN: 0-12-733920-5

Send payment with order and save postage and handling. Prices are in U.S. dollars and are subject to change without notice.

\section{Academic Press, Inc.}

A Subsidiary of

Harcourt Brace Jovanovich, Publishers

New York - London - Toronto - Sydney

San Francisco

111 FIFTH AVENUE, N.Y., N.Y. 10003 


\section{La Rochelle and the Atlantic Economy during the Eighteenth Century}

\section{John G. Clark}

The saga of the rise and fall of one of pre-Revolutionary France's most dynamic port cities - La Rochelle. John G. Clark demonstrates that the city's economic success hinged on the fortunes of ninety to one hundred négotiant-armateurs, members of an elite merchant class. Combining social and economic history, Clark explores both the lives of these pivotal individuals and the thriving financial structure they created.

The breadth of Clark's study, coupled with his clear and readable prose style, makes La Rochelle and the Atlantic Economy during the Eighteenth Century a valuable resource for anyone interested in family, social, economic, or political history, as well as in the history of preRevolutionary France.

$\$ 24.00$

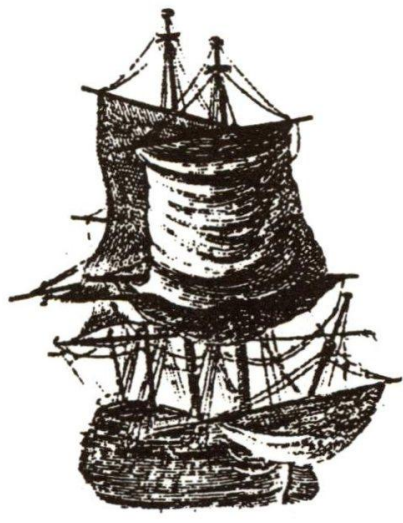

\section{The Revolution of 1525}

The German Peasants' War from a New Perspective

\section{Peter Blickle}

\section{translated by $H$. C. Erik Midelfort and Thomas A. Brady, Jr.}

This is the first comprehensive study of the event Friedrich Engels called "the grand est revolutionary effort of the German people" to appear in English in over a century. First published in German in 1975, it has been praised as the best book available about this early revolt against the injustices of feudalism.

Peter Blickle's interpretation sheds new light on the economic, social, political, and ideological dimensions of the crisis and offers an original analysis of the causes, goals, and consequences of the great rebellion.

The Johns Hopkins University Press

Baltimore, Md. 21218 


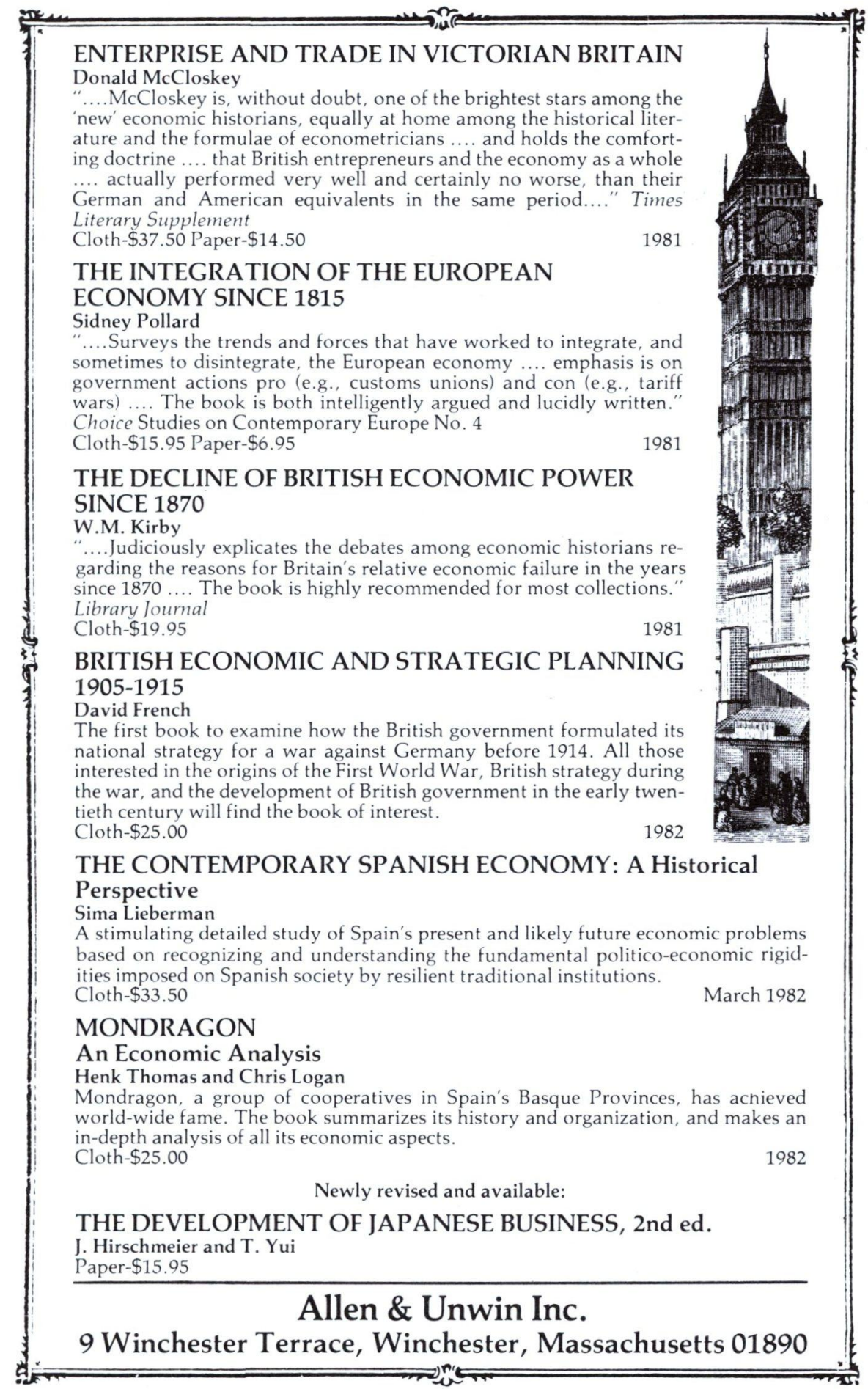

